\title{
PELAYANAN ADMINISTRASI UMUM DI MAHKAMAH KONSTITUSI
}

\author{
Mohammad Siddiq
}

\begin{abstract}
Abstrak
Mahkamah Konstitusi Republik Indonesia (MKRI) sebagai lembaga negara yang berfungsi menjaga konstitusi dituntut untuk senantiasa memberikan pelayanan kepada masyarakat sesuai dengan bidang yang menjadi kewenangannya. Pada konsep sederhana, semakin tinggi tingkat kepuasan penerima layanan, maka semakin berkualitas layanan, begitupun sebaliknya. Perlu disadari, bahwa pelayanan publik tidak hanya berorientasi pada konsumen di luar MKRI saja, melainkan juga kepada pegawai MKRI itu sendiri. Salah satu pelayanan yang diberikan kepada para pegawainya dalam rangka mendukung pelaksanaan tugas dan fungsi MK adalah pelayanan administrasi umum. Penelitian ini berupaya mengukur pelayanan administrasi umum melalui SERVQUAL (service quality) yang terdiri atas 5 dimensi, yaitu: keandalan (reliability), keterjaminan (assurance), keberwujudan (tangiblity), rasa empati (emphaty), responsivitas (responsiveness). Hasil penelitian ini menunjukkan bahwa secara umum, pelayanan administrasi umum MKRI dinilai cukup baik dalam persepsi para pegawainya, dengan skor keseluruhan sebesar 70,28. Suasana kerja di MKRI mendapatkan skor tertinggi, yaitu sebesar 76,50. Sementara dukungan dari atasan mendapatkan skor terendah yaitu sebesar 70,89. Adapun, kepuasan kerja, produktivitas kerja, dan keseimbangan kerja mendapatkan skor masing-masing 74,66, 73,50, dan 57,69.
\end{abstract}

Kata kunci: Administrasi, Kualitas Pelayanan Publik, Mahkamah Konstitusi

\section{PENDAHULUAN}

Globalisasi yang terjadi di segala bidang, seperti politik, ekonomi, dan teknologi ternyata membawa dampak yang signifkan bagi perubahan sosial. Distribusi informasi yang cepat dan dengan cakupan yang luas mampu menjadi input bagi persepsi publik. Masyarakat yang semula menganggap biasa pada pelayanan yang diberikan pemerintah, kemudian menjadi menuntut pelayanan yang prima dari pemerintah. Tuntutan tersebut kemudian mampu mengubah paradigma pemerintah terhadap tata kelola penyelenggaraan pelayanan publik yang mengarah pada pelayanan yang cepat tanggap, memiliki daya saing, dan berkualitas.

Paradigma baru ini mengakibatkan hubungan antara masyarakat dengan birokrat lebih menekankan kepada kepentingan masyarakat, sehingga pemerintah tidak lagi menjadi sosok institusi yang angkuh dan tidak tersentuh kritik. Partisipasi masyarakat menjadi faktor utama dalam good corporate governance (Larasati, 2008). Bahkan Kristiadi (1994) dalam Wijayanto, 2009 menyatakan bahwa idealnya pelayanan yang diterima oleh publik merupakan keputusan bersama antara birokrat dan publik.

Melalui Undang-Undang No 25 Tahun 2009 mengenai Pelayanan Publik. Pemerintah berusaha meningkatkan kualitas pelayanan publik dan membangun kepercayaan dari masyarakat dengan berdasarkan pada azas: 1) kepentingan umum; 2) kepastian hukum; 3) kesamaan hak; 4) keseimbangan hak dan kewajiban; 5) keprofesionalan; 6) partisipatif; 7) persamaan 
perlakuan/tidak diskriminatif; 8) keterbukaan; 9) akuntabilitas; 10) fasilitas dan perlakukan khusus bagi kelompok rentan; 11) ketepatan waktu; dan 12) kecepatan, kemudahan dan keterjangkauan.

Pada konsep sederhana, tolok ukur dari kualitas pelayanan yang tinggi adalah terlihat dari kepuasan dari penerima layanan. Semakin tinggi tingkat kepuasan penerima layanan, maka semakin berkualitas layanan, namun semakin rendah tingkat kepuasan pelayanan, maka tingkat kualitas layanan semakin rendah pula. Untuk memenuhi pelayanan yang memuaskan diperlukan standar pelayanan. Standar pelayanan adalah suatu tolok ukur yang dipergunakan untuk acuan penilaian kualitas pelayanan sebagai komitmen atau janji dari pihak penyedia pelayanan kepada penerima layanan untuk memberikan pelayanan yang berkualitas. Sehingga, pelayanan berkualitas adalah pelayanan yang cepat, menyenangkan, tidak mengandung kesalahan, serta mengikuti proses dan prosedur yang telah ditetapkan terlebih dahulu. (LAN, 2003:78).

Mahkamah Konstitusi Republik Indonesia (MKRI) sebagai lembaga negara yang berfungsi menjaga konstitusi guna tegaknya prinsip konstitusionalitas hukum di negara Indonesia ini dituntut harus senantiasa memberikan pelayanan kepada masyarakat sesuai dengan bidang yang menjadi kewenangannya, yaitu: 1) Pengujian Undang-Undang Dasar 1945; 2) memutus sengketa kewenangan antar lembaga negara; 3) memutus pembubaran partai politik; dan 4) memutus perselisihan tentang hasil pemilu (Gaffar, 2009). Dengan demikian yang menjadi konsumen dari MKRI adalah lembaga negara, partai politik, dan masyarakat peserta pemilu.

Perlu disadari, bahwa pelayanan publik juga tidak hanya berorientasi ke konsumen di luar MK saja, melainkan juga kepada pegawai MK itu sendiri. Salah satu pelayanan yang diberikan kepada para pegawainya dalam rangka mendukung pelaksanaan tugas dan fungsi MK adalah pelayanan administrasi umum. Pelayanan administrasi umum diberikan dalam bentuk pelayanan keuangan, kesehatan, kepegawaian serta pelayanan sarana dan prasarana.

Salah satu alat ukur penelitian yang sering digunakan dalam penelitian mengenai pelayanan adalah metode SERVQUAL yang terdiri atas 5 dimensi, yaitu: keandalan (reliability), keterjaminan (assurance), keberwujudan (tangiblity), rasa empati (emphaty), responsivitas (responsiveness) atau yang disingkat dengan RATER. Untuk mengetahui tingkat kualitas pelayanan administrasi umum di lingkungan Mahkamah Konstitusi, maka dilakukan penelitian terhadap 5 dimensi tersebut. Penelitian ini diharapkan mampu memberikan kontribusi bagi MKRI sebagai masukan atas kondisi dari pelayanan administrasi umum dari sudut pandang internal MKRI, sekaligus menjadi bahan untuk penyusunan program pengembangan pegawai terutama dalam upaya meningkatkan pelayanan administrasi umum guna mewujudkan standar pelayanan yang profesional di MKRI.

\section{METODE}

Penelitian ini menggunakan pendekatan kuantitatif dengan metode survei. Dalam penelitian ini, terdapat beberapa variabel penelitian yang diturunkan menjadi indikator variabel penelitian yang selanjutnya disusun dalam butir-butir pernyataan pada kuesioner. Hal tersebut dapat dilihat pada tabel berikut:

Tabel 1. Variabel, Dimensi dan Indikator Penelitian

\begin{tabular}{|l|l|l|}
\hline \multicolumn{1}{|c|}{ Variabel } & \multicolumn{1}{|c|}{ Dimensi } & \multicolumn{1}{c|}{ Indikator } \\
\hline $\begin{array}{l}\text { Administrasi } \\
\text { Umum }\end{array}$ & Tangibles & Ketersediaan sarana fisik pelayanan adminsitrasi umum \\
\cline { 2 - 3 } & Reliability & $\begin{array}{l}\text { Layanan akurat, tepat waktu, dan dapat dipercaya } \\
\text { (kompeten) }\end{array}$ \\
\hline
\end{tabular}




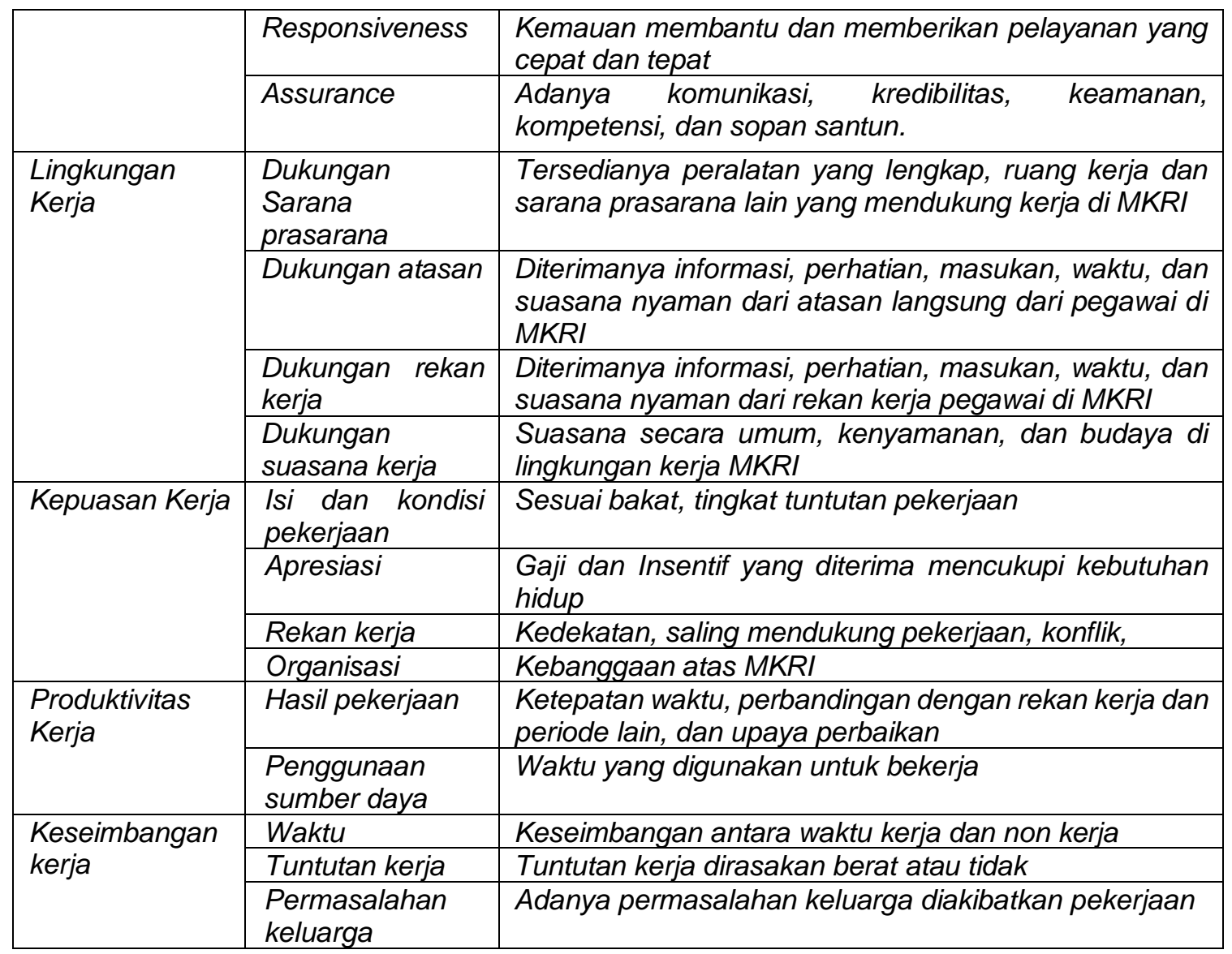

Populasi dalam penelitian ini adalah seluruh pegawai MKRI sejumlah 225 orang. Sedangkan sample dari penelitian ini sebesar 95,11 persen dari populasi, yaitu sejumlah 214 orang. Data yang digunakan dalam penelitian ini merupakan data primer yang diperoleh secara langsung dari responden penelitian melalui kuesioner. Adapun cronbach alpha digunakan untuk menguji tingkat reliabilitas data. Analisis data dilakukan dengan 2 tahap, yaitu: Analisis diskriptif dengan menggunakan tabulasi dan grafik untuk menggambarkan distribusi dan keterkaitan dari masingmasing variabel. Analisis Structural Equation Modeling (SEM) yaitu mengukur keterkaitan variabel-variabel penelitian dengan bantuan software Lisrell versi 8.8. Analisis ini digunakan dengan mempertimbangkan bahwa variabel persepsi atas kualitas pelayanan, kepuasan kerja, produktivitas dan keseimbangan kerja merupakan variabel latent yang tidak dapat langsung diobservasi, sehingga harus direfleksikan oleh variabel-variabel lainnya. Wawancara juga dilakukan untuk melengkapi data yang diperoleh melalui kuesioner. Hal tersebut dapat dilihat pada gambar berikut. 


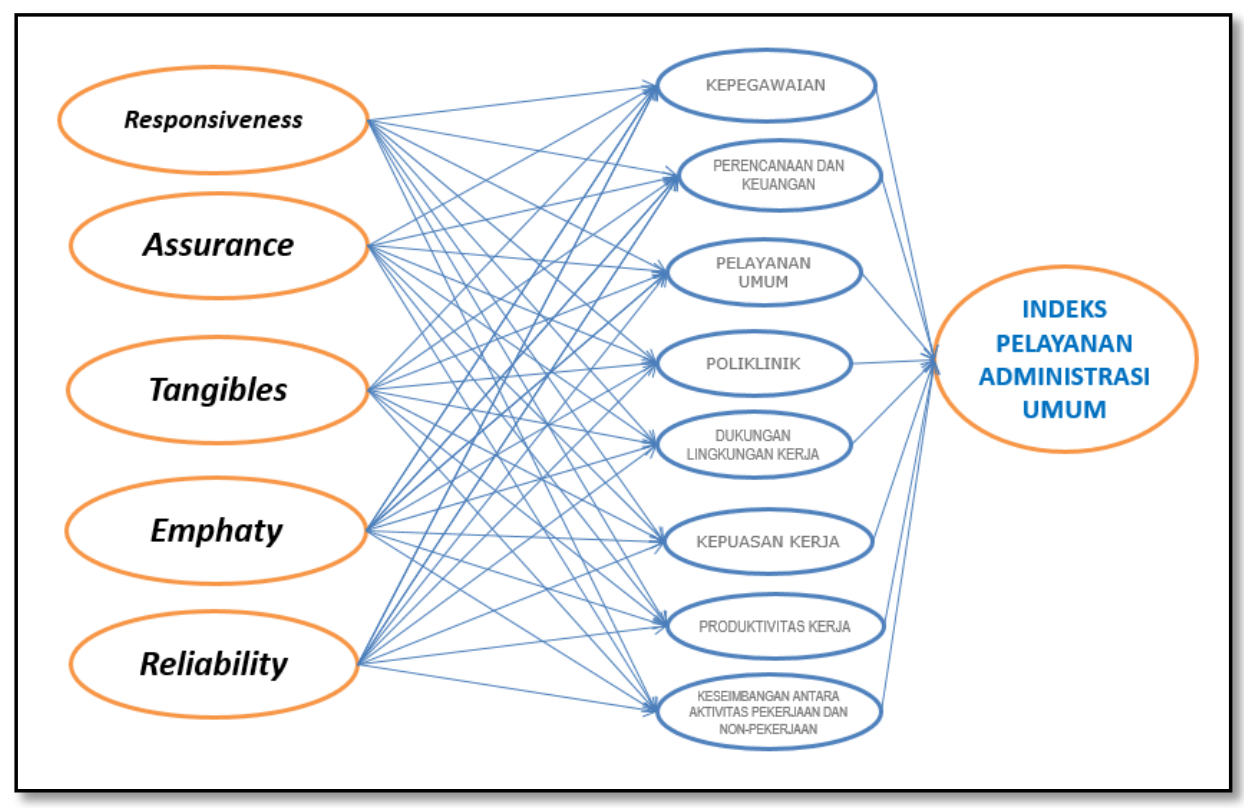

Gambar 1. Indeks Pelayanan Administrasi Umum

HASIL

Demografi Responden. Sebagaimana diketahui bahwa responden penelitian ini adalah 95,11 persen dari seluruh pegawai MKRI yang secara demografik 61 persen adalah laki-laki dan 39 persen adalah perempuan. Hal tersebut dapati dilihat pada gambar berikut.

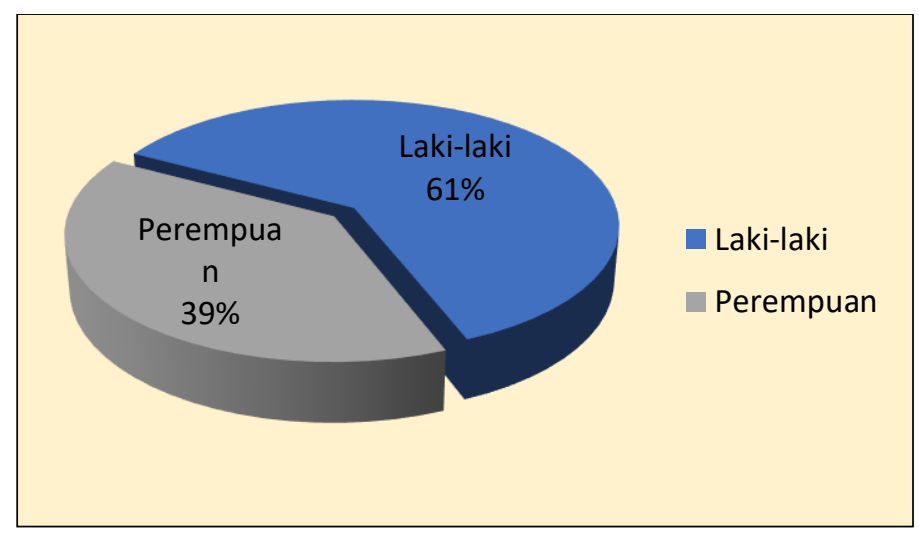

Gambar 2. Jenis Kelamin

Dilihat dari lamanya bekerja sebagai pegawai MKRI, sebagian besar dari responden, yaitu sebesar 43 persen atau 92 orang telah bekerja di MKRI selama lebih dari 5 tahun. Namun Demikian, ada juga yang bekerja belum lebih dari 2 tahun, yaitu sebanyak 22 persen atau 47 orang. Dengan demikian, sebagian responden dapat dianggap cukup memahami kondisi pelayanan administrasi umum baik secara normatif sesuai peraturan maupun secara aktualnya, sehingga mampu mempersepsikannya dengan baik. 


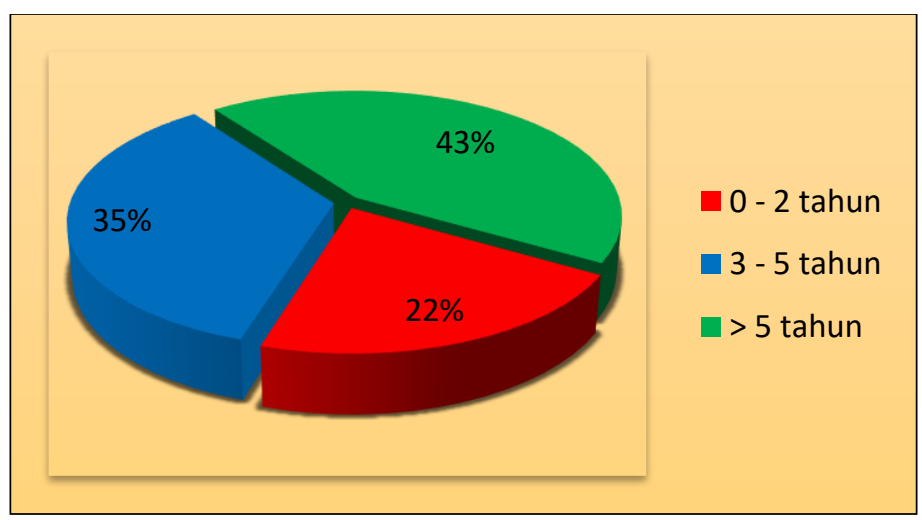

Gambar 3. Lama Kerja Pegawai

Ditinjau dari sisi usia responden, 2 persen telah berusia di atas 51 tahun, 15 persen berusia 4150 tahun, 42 persen telah berusia 31-40 tahun, dan 41 persen berusia di bawah 30 tahun. Jika di ambil nilai rata-rata dari responden adalah 33,5 tahun. Usia tersebut secara keseluruhan dapat digolongkan telah dewasa dan mempunyai pemikiran yang matang dan obyektif dalam menilai dan mempersepsikan kondisi yang ada.

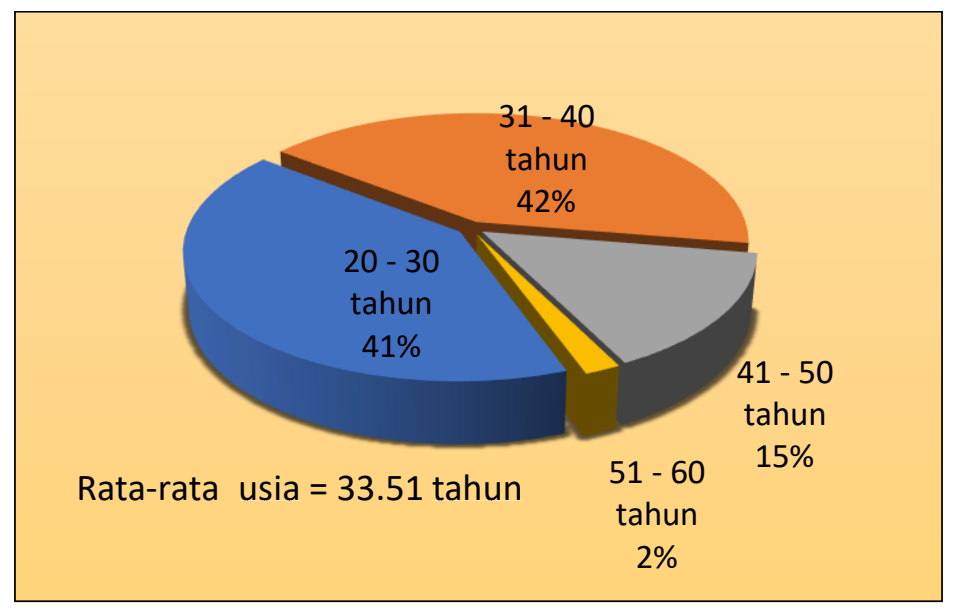

Gambar 4. Usia Responden

Obyektivitas persepsi juga didukung oleh tingkat pendidikan dari responden. Sebagian besar responden, yaitu 86 persen merupakan lulusan dari pendidikan tinggi, yaitu sarjana dan master. Sedangkan 14 persen merupakan lulusan SLTA dan Diploma. 


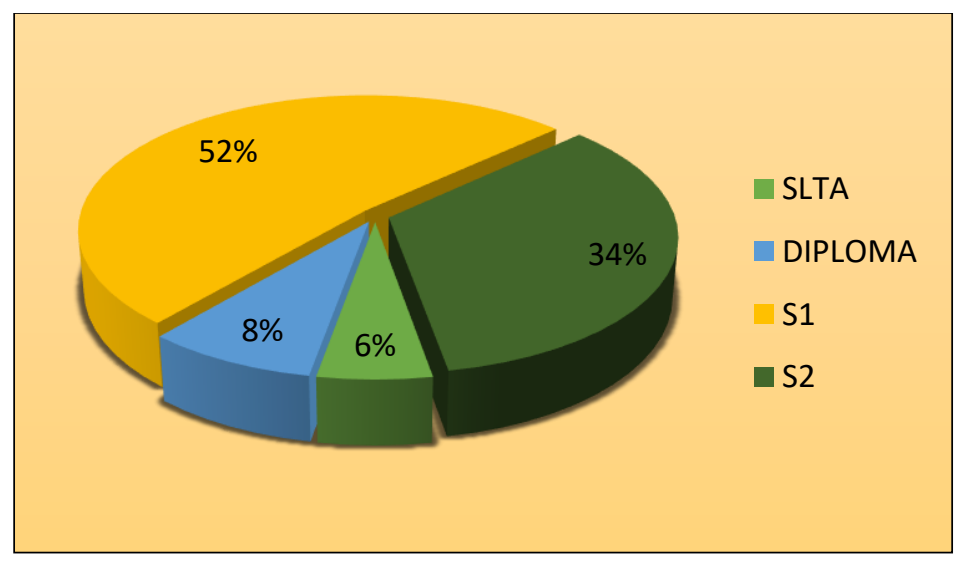

Gambar 5. Latar Belakang Pendidikan

Distribusi responden dilihat dari biro tempat responden ditugaskan, sebanyak 22 persen responden bertugas di Biro Umum, 20 persen di Biro Hubungan Masyarakat dan Protokol, 19 persen di Administrasi Perkara dan Persidangan,16 persen di Pusat Penelitian dan Pengkajian, 15 persen di Biro Perencanaan dan Keuangan, serta 8 persen bertugas di Bagian lain, yang meliputi Kepaniteraan dan Satuan Pengawasan Intern. Berdasarkan jabatannya, sebagian besar responden merupakan staff, yaitu sebesar 74 persen.

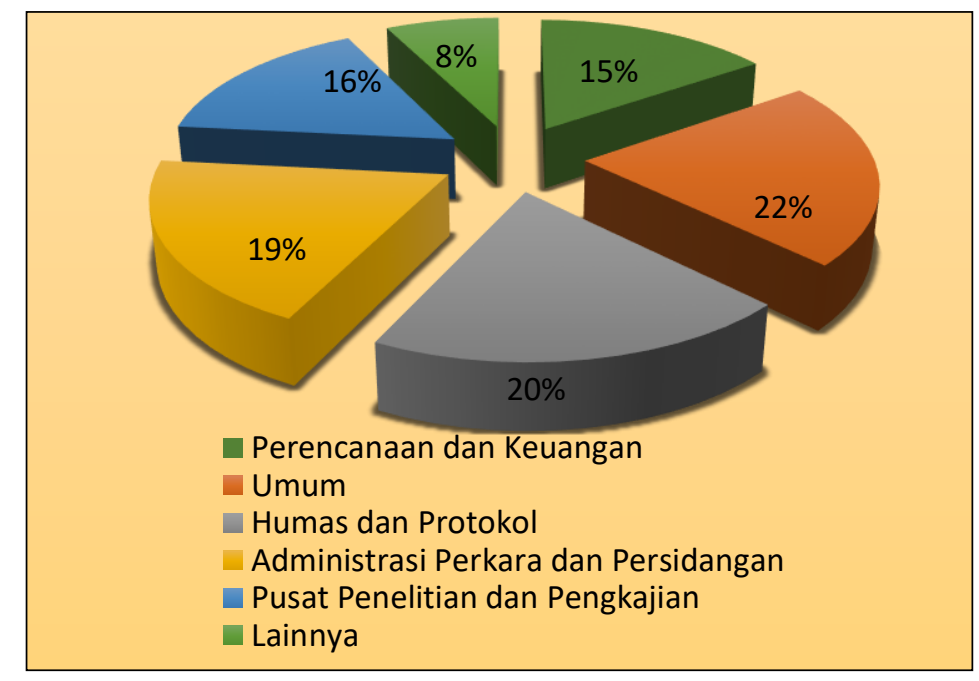

Gambar 6. Demografi Responden berdasarkan Unit Organisasi

Pelayanan Administrasi Umum di MKRI. Seperti telah dijelaskan sebelumnya, bahwa pengukuran pelayanan administrasi umum dilakukan dengan menggunakan dimensi SERVQUAL yang meliputi tangibles, reliability, responsiveness, assuance, dan emphaty. Penelitian dilakukan atas pelayanan administrasi umum yang dilakukan oleh Bagian Kepegawaian, Bagian Perencanaan dan Keuangan, Bagian Umum, dan Bagian Poliklinik.

Hasil scoring atas persepsi pelayanan administrasi dari keempat bagian tersebut, diketahui bahwa Poliklinik dipersepsikan mempunyai pelayanan administrasi umum yang lebih baik dibandingkan dengan bagian lain, yaitu dengan skor sebesar 74,63. Nilai ini lebih tinggi dibandingkan dengan nilai skor administrasi umum secara keseluruhan, yaitu sebesar 70,28. 
Sementara itu, persepsi pelayanan pada Bagian Kepegawaian perlu mendapatkan perhatian lebih, mengingat nilainya lebih rendah dibandingkan bagian lainnya, yaitu sebesar 68,96.

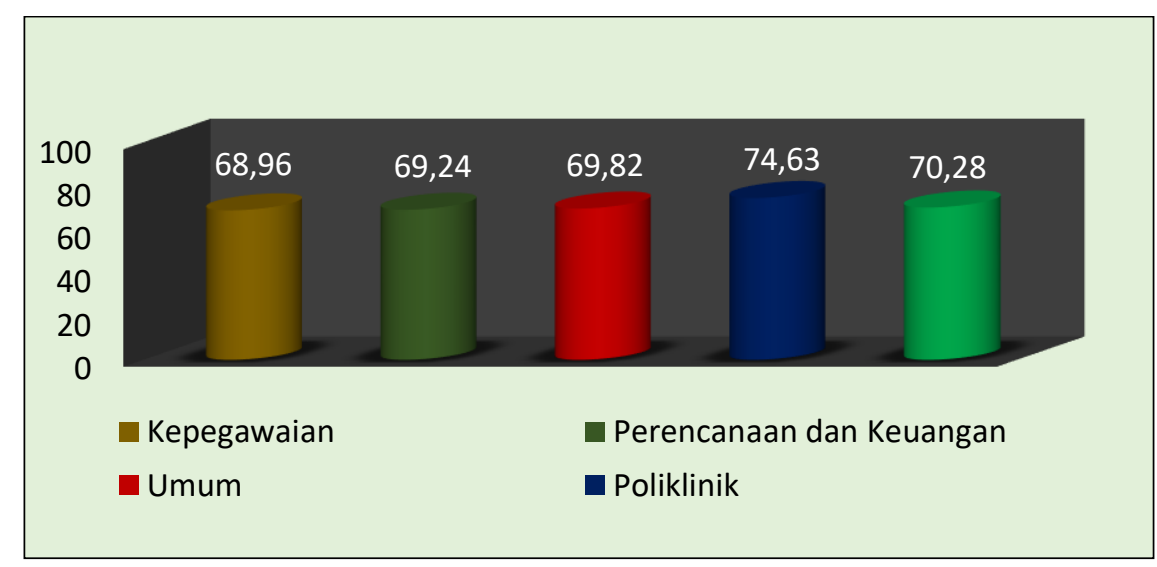

Gambar 7. Pelayanan Administrasi Umum

Penilaian kualitas berdasarkan atas dimensi SERVQUAL pada pelayanan administrasi umum secara keseluruhan, memberikan informasi mengenai dimensi mana yang unggul dan perlu mendapat perhatian khusus pada keempat bagian yang diteliti. Pada dimensi tangibility, pelayanan administrasi umum dinilai sudah baik. Hal ini ditunjukkan dengan skor yang lebih tinggi dibandingkan dengan dimensi lainnya. Keunggulan terutama pada bangunan dan ruangan pelayanan administrasi umum. Sementara yang perlu mendapatkan perhatian lebih adalah dimensi reliability, mengingat skor yang diperolehnya lebih rendah dibandingkan dimensi lainnya.

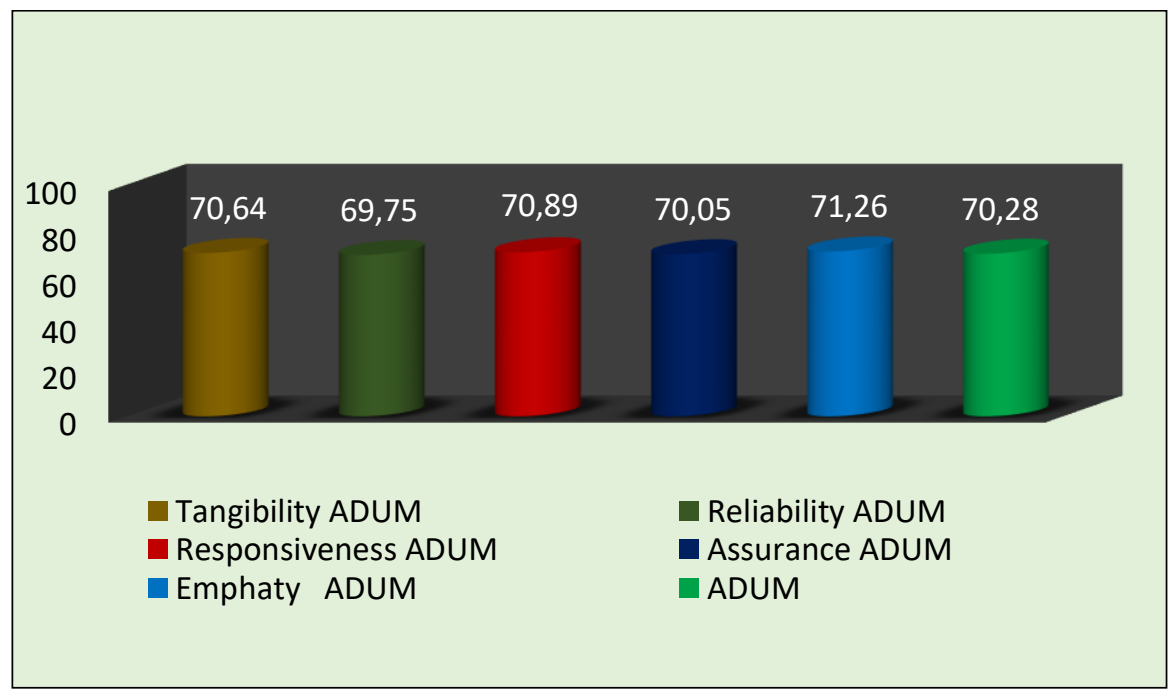

Gambar 8. Tingkat Kepuasan Pelayanan Administrasi Umum

Lingkungan kerja di MKRI. Persepsi lingkungan kerja dinilai atas 4 (empat) dimensi, yaitu dukungan sarana dan prasaran, dukungan atasan langsung, dukungan rekan kerja, dan dukungan suasana kerja. Berdasarkan masing-masing dimensi tersebut, secara umum suasana kerja di MKRI cenderung dirasakan menyenangkan bagi pegawainya karena nyaman dan saling menghargai. Hal ini dibuktikan dengan skor suasana kerja memperoleh nilai tertinggi dibandingkan dimensi lainnya. Hal tersebut dapat dilihat pada gambar berikut. 


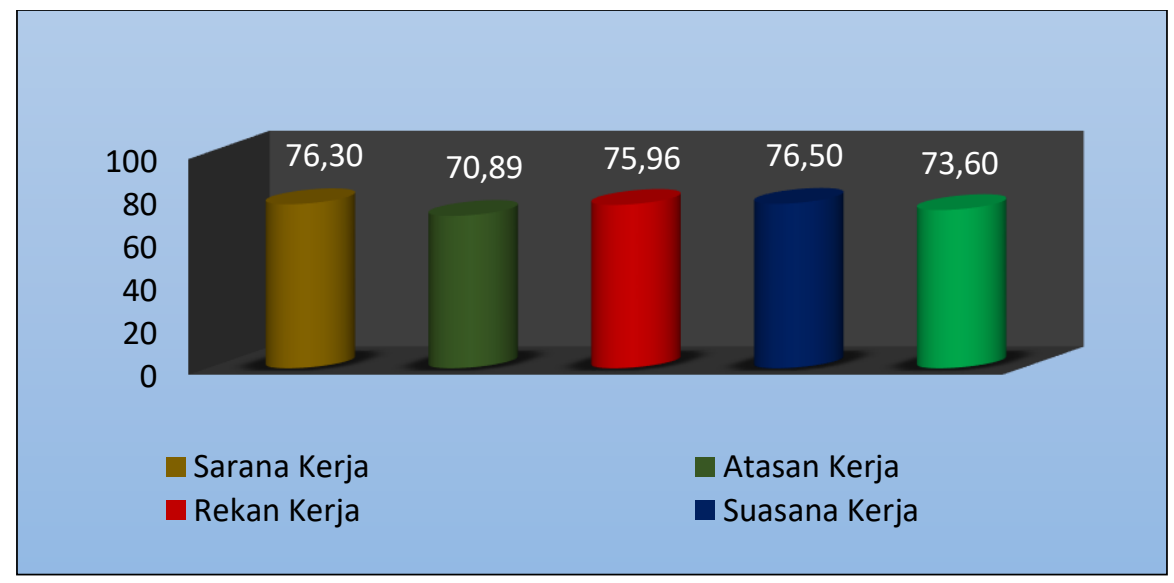

Gambar 9. Lingkungan Kerja

Sarana kerja yang disediakan juga sudah mencukupi bagi pegawai. Demikian juga dukungan dari rekan kerja sudah baik, terutama dalam hal bertukar informasi dan kenyamanan mengemukakan pendapat. Semakin lama bekerja sama, semakin mendapatkan manfaat. Hal ini terukur dengan skor yang semakin meningkat seiring dengan lamanya bekerja di MKRI.

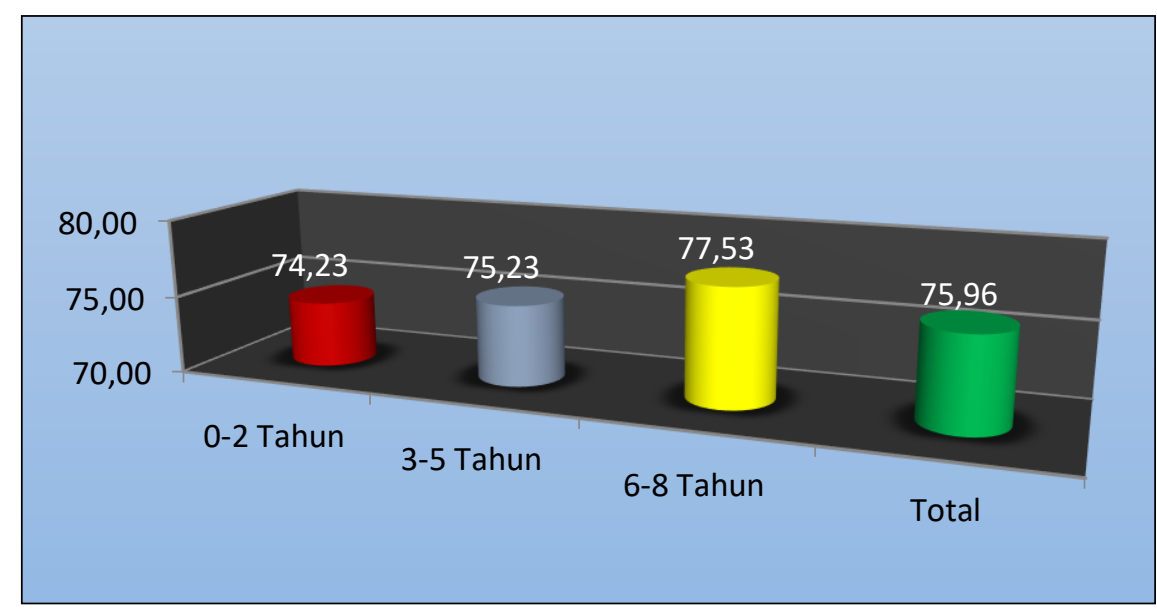

Gambar 10. Persepsi Responden Terhadap Rekan Kerja Berdasar Lama Berkerja di MKRI

Hal yang perlu mendapatkan perhatian lebih adalah dukungan dengan atasan. Skor persepsi pegawai terhadap dukungan atasan relatif lebih rendah daripada dimensi lain dalam lingkungan kerja. Perhatian terutama pada dukungan karier dari atasan langsung kepada pegawai dan tanggap atas kesulitan pegawai serta bersedia membantunya.

Kepuasan Kerja Pegawai MKRI. Pengukuran kepuasan kerja dilihat dari 4 hal, yaitu kepuasan terhadap isi dan kondisi pekerjaan, apresiasi, rekan kerja, dan kepuasan kepada organisasi. Terdapat 2 (dua) sumber kepuasan pegawai, yaitu penghasilan yang tinggi dari MKRI dan kebanggaan pegawai bekerja di MKRI. Ini merupakan modal bernilai tinggi bagi pengembangan MKRI. Namun, hal yang perlu diperhatikan adalah mengenai penempatan kerja. Pegawai merasa pekerjaannya tidak sesuai dengan keahliannya. Hal lain yang diketahui adalah bahwa pegawai sering merasa frustrasi bekerja di MKRI.

Perbedaan usia mempengaruhi persepsi yang dirasakan mengenai kepuasannya selama bekerja di MKRI. Berdasarkan data yang diperoleh diketahui bahwa semakin dewasa usia pegawai, maka 
semakin merasa puas bekerja di MKRI dan memberikan skor yang lebih besar daripada yang muda. Demikian juga dengan masa kerja. Semakin lama masa kerja di MKRI, semakin memberikan skor yang besar terhadap kepuasan kerja. Hal ini dimungkinkan karena bertumbuhnya loyalitas pegawai terhadap MKRI.

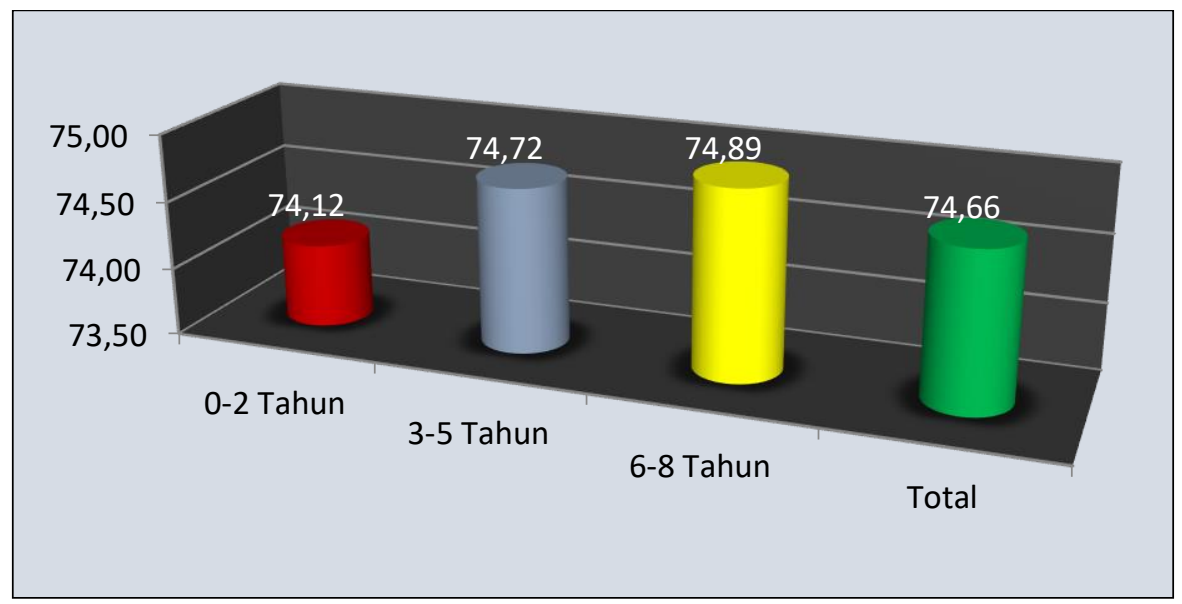

Gambar 11. Kepuasan Kerja Pegawai berdasarkan Masa Kerja

Produktivitas Kerja MKRI. Persepsi pegawai atas produktivitas kerja di MKRI diukur menggunakan persepsi atas hasil pekerjaan dan penggunaan sumber daya. Terdapat 12 pertanyaan mengenai persepsi produktivitas kerja. Secara total, skor produktivitas seluruh responden adalah 73,50. Melalui perbandingan antara skor responden berdasarkan jenis kelamin, diketahui bahwa skor persepsi produktivitas kerja bagi pegawai laki-laki lebih tinggi dibandingkan dengan skor pegawai perempuan. Sementara persepsi yang diberikan oleh pegawai yang usianya lebih muda lebih sedikit dibandingkan para seniornya. Sementara jika dilihat dari berdasarkan lamanya bekerja di MKRI, persepsi yang dibuat oleh pegawai menunjukkan bahwa semakin lama bekerja di MKRI justru merasa bahwa produktivitasnya tidak sebesar mereka yang lebih junior masa kerjanya.

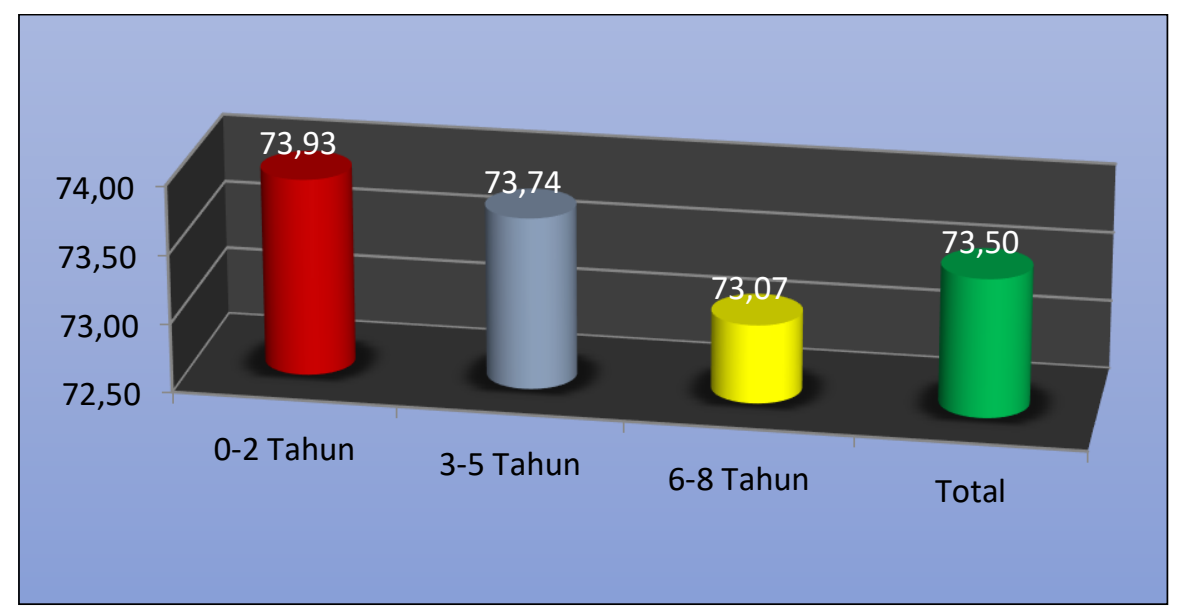

Gambar 12. Produktivitas Kerja Berdasarkan Lama Kerja di MK

Keseimbangan Kerja di MKRI. Keseimbangan kerja dalam penelitian ini diukur dengan memperhatikan persepsi reasponden atas waktu, tuntutan kerja, dan permasalahan keluarga yang ditimbulkan akibat pekerjaan. Dengan menggunakan 6 (butir) pernyataan diperoleh skor 
seluruh responden sebesar 57,69. Nilai ini relatif rendah dibandingkan skor atas variabel-variabel lainnya. Dengan membandingkan antara skor yang diberikan oleh pegawai berdasarkan jenis kelaminnya, diketahui bahwa pegawai perempuan memberikan skor yang lebih tinggi dibandingkan pegawai laki-laki. Hal tersebut unik, mengingat biasanya pegawai perempuan akan cenderung menginginkan waktu yang lebih banyak untuk keluarganya, berbeda dengan pegawai laki-laki yang menyadari tugasnya sebagai kepala rumah tangga sekaligus pencari nafkah, sehingga bisa memberikan waktunya dan pikirannya secara maksimal kepada pekerjaan.

Berdasarkan temuan ini dapat diinterpretasikan bahwa keseimbangan pekerjaan di MKRI sudah memperhatikan masalah keseimbangan kerja, sehingga cukup membuat nyaman bagi pegawai perempuan, meskipun belum pada level yang ideal. Interpretasi lain adalah pegawai perempuan di MKRI sudah sangat profesional, mampu membagi keseimbangan antara perkerjaan dengan keluarga.

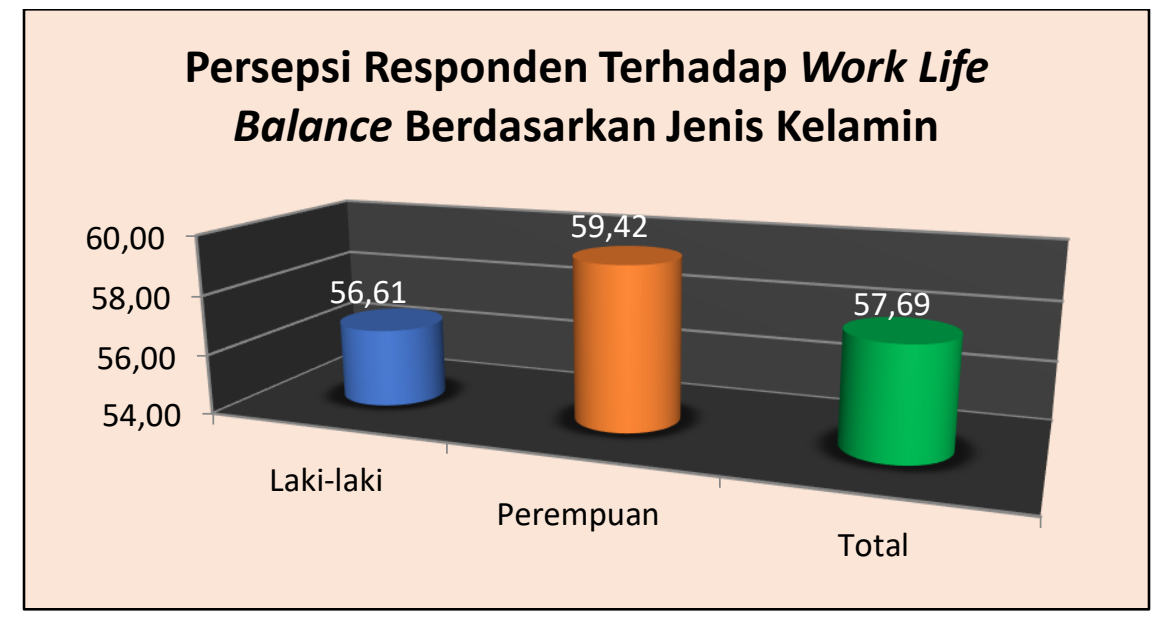

Gambar 13. Keseimbangan Kerja di MKRI

Keterkaitan Persepsi. Melalui analisis Structural Equation Modeling (SEM) diperoleh model keterkaitan persepsi sebagai berikut: 


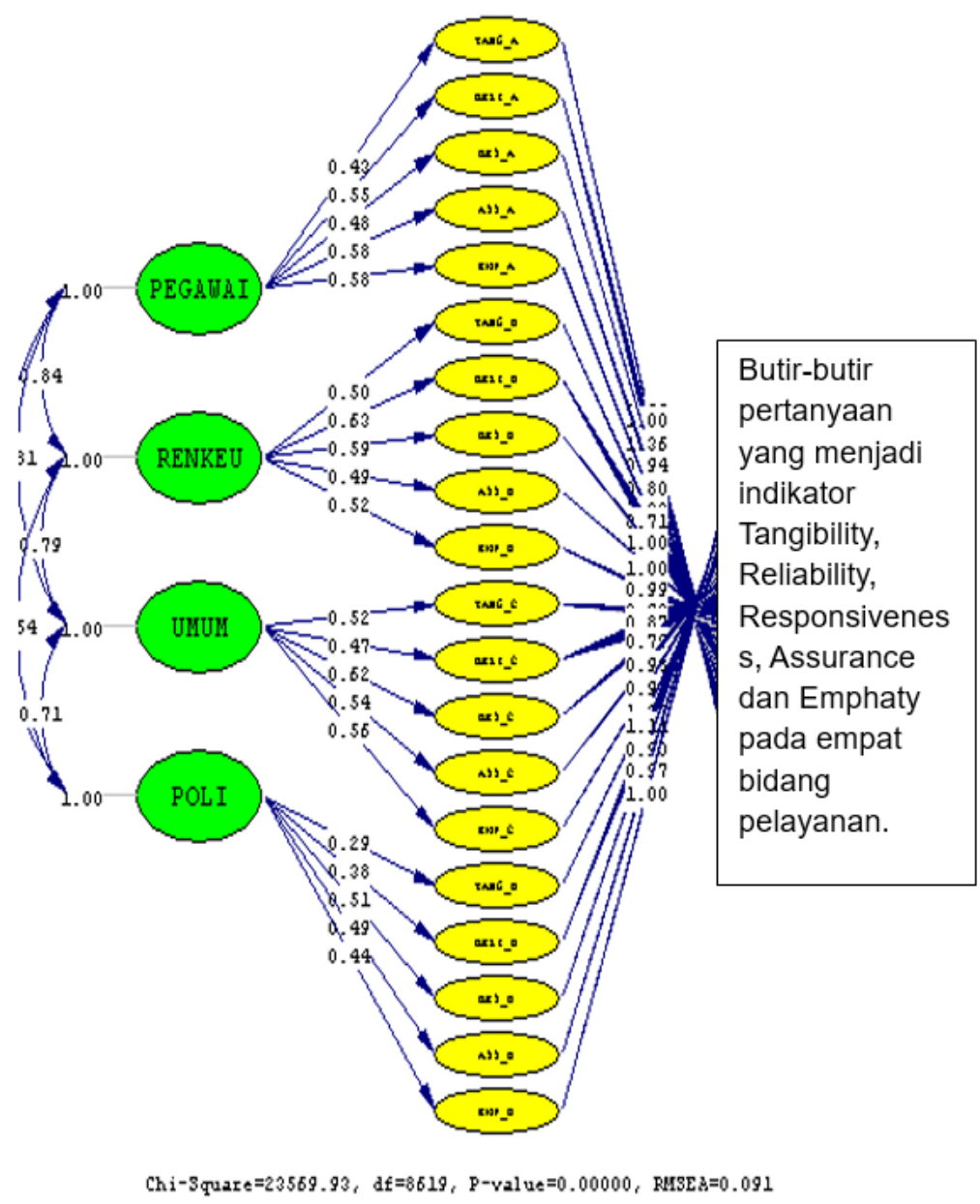

Gambar 14. Keterkaitan antar Variabel Administrasi Umum

Variabel persepsi atas Kualitas Pelayanan Kepegawaian (Pegawai), Kualitas Pelayanan Perencanaan dan Keuangan (RenKeu), Kualitas Pelayanan Umum (Umum), dan Kualitas Pelayanan Poliklinik (Poli), merupakan variabel latent yang tidak dapat diobservasi secara langsung. Untuk itu direfleksikan dengan dimensi SERVQUAL, yaitu tangibility, reliability, responsiveness, assurance, dan emphaty.

Hasil menunjukkan bahwa variabel pegawai direfleksikan terutama oleh assurance dan emphaty, dengan loading factor sebesar 0,58. Variabel Renkeu direflesikan terutama oleh reliability, dengan loading factor sebesar 0,63 . Sementara variabel umum dan poli direfleksikan terutama oleh responsiveness dengan loading factor sebesar 0,62 dan 0,51. Keempat variabel latent tersebut kemudian secara signifikan mampu merefleksikan variabel latentpelayanan administrasi umum (Adum). 
Sementara variabel latent lainnya adalah kepuasan kerja (Puas), produktivitas kerja (Prod), dan keseimbangan kerja atau work life balance (WLF) yang mencerminkan persepsi kepuasan, produktivitas kerja, dan keseimbangan kerja. Variabel-variabel tersebut secara signifikan direfleksikan oleh pernyataan-pernyataan dalam kuesioner.

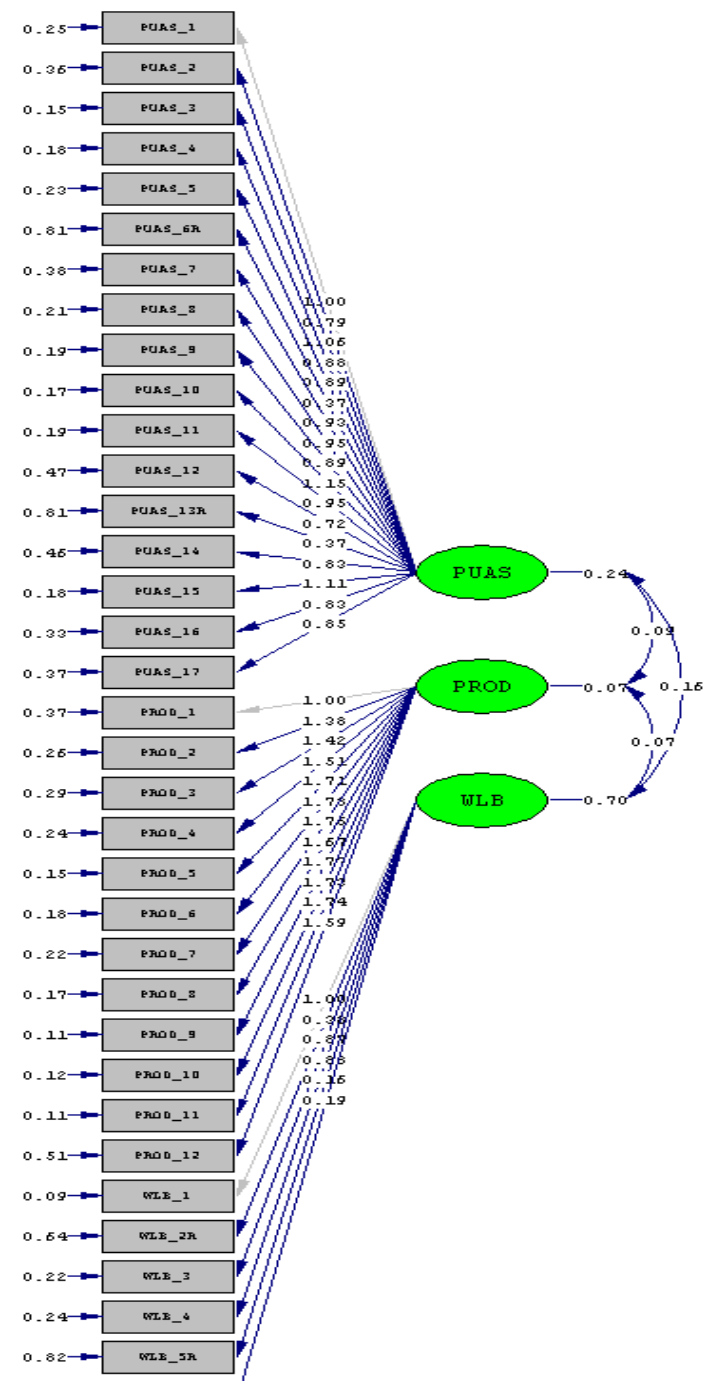

Gambar 15. Keterkaitan Persepsi Kepuasan, Produktivitas dan Keseimbangan Kerja

Kemudian variabel-variabel tersebut diuji keterkaitannya. Diketahui bahwa variabel Adum direfleksikan oleh 4 bagian, dengan loading factor tertinggi pada kepegawaian, yaitu sebesar 0,91 . Variabel Adum secara signifikan mempengaruhi kepuasan kerja dengan koefisien sebesar 0,35 , namun tidak mempengaruhi produktivitas. Sementara lingkungan kerja mempengaruhi produktivitas sekaligus kepuasan kerja dengan koefisien masing-masing 0,39 dan 0,41. 
Sedangkan keseimbangan kerja tidak mempunyai pengaruh signifikan baik kepada produktivitas maupun kepuasan kerja.

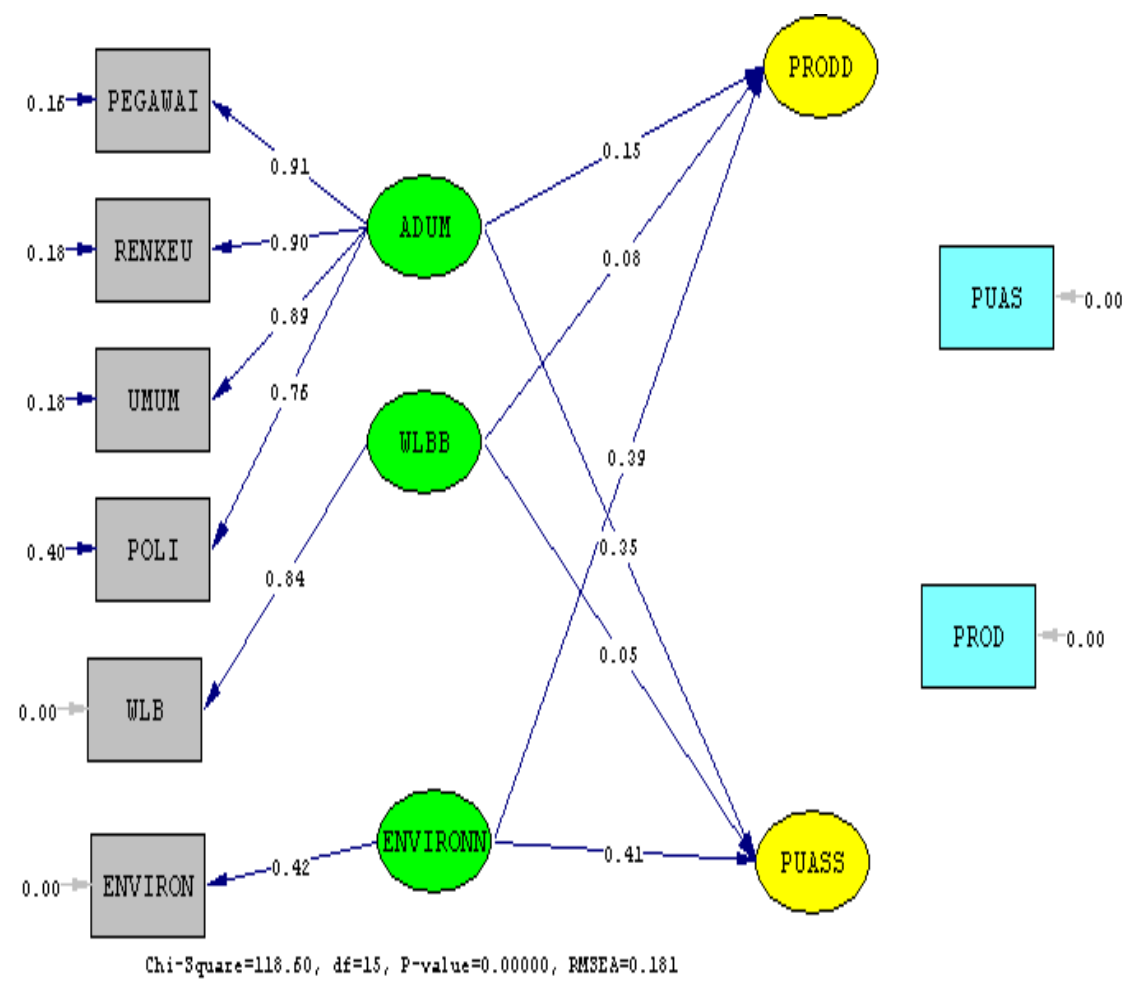

Gambar 16. Keterkaitan antar Variabel

\section{KESIMPULAN}

Penelitian ini bertujuan untuk menganalisis persepsi pegawai MKRI atas pelayanan administrasi umum, lingkungan kerja, kepuasan kerja, produktivitas kerja dan keseimbanga kerja, serta keterkaitan antara persepsi-persepsi tersebut. Dengan responden sebanyak 214 orang pegawai, dapat diambil keseimpulan bahwa kualitas pelayanan administrasi umum pada Bagian Kepegawaian, Bagian Perencanaan dan Keuangan, Bagian Umum, dan Bagian Poliklinik di MKRI cukup baik, dengan skor keseluruhan sebesar 70,28. Di antara bagian-bagian terebut, Bagian Poliklinik memdapatkan skor yang lebih tinggi dibandingkan bagian lain, yaitu sebesar 74, 63 . Sementara Bagian Kepegawaian perlu mendapatkan perhatian lebih mengingat skornya lebih rendah dibandingkan bagian-bagian lain, yaitu sebesar 68,96.

Persepsi pegawai atas lingkungan kerja di MKRI menunjukkan hasil yang cukup baik, dengan skor keseluruhan sebesar 73,60. Pada lingkungan kerja tersebut, suasana kerja di MKRI mendapatkan skor tertinggi, yaitu sebesar 76,50. Sementara dukungan dari atasan mendapatkan skor terendah yaitu sebesar 70,89. Sementara kepuasan kerja, produktivitas kerja, dan keseimbangan kerja mendapatkan skor masing-masing 74,66, 73,50, dan 57,69. Dari hasil analisis Struktural Equation Modeling, diketahui bahwa variabel Adum secara signifikan mempengaruhi kepuasan kerja namun tidak mempengaruhi produktivitas. Sementara lingkungan 
kerja mempengaruhi produktivitas sekaligus kepuasan kerja, sedangkan keseimbangan kerja tidak mempunyai pengaruh signifikan baik kepada produktivitas maupun kepuasan kerja.

Mempertimbangkan keterkaitan antara variabel-variabel tersebut, maka rekomendasi yang diberikan kepada MKRI adalah :

1. Perlu dilakukan peningkatan kualitas pelayanan administrasi umum dalam rangka meningkatkan kepuasan kerja pegawai MKRI. Adapun upaya yang dilakukan adalah: a) Regenerasi dan penambahan peralatan kerja seperti komputer, scan, printer, dan fax; b) Peningkatan lebih lanjut fasilitas kesehatan berupa penambahan jadwal dokter spesialis, penambahan peralatan check kesehatan, alat fisioterapi, penyempurnaan proses pembuatan rujukan ke rumah sakit, serta upgrade kartu Askes; c) Penyempurnaan buku pedoman mengenai SOP setiap unit kerja, dan didistribusikan kepada seluruh pegawai. kepedulian pegawai; d) Mengembangkan ICT untuk meningkatkan komunikasi yang efektif dan efisien; e) Meningkatkan jumlah dan kualitas perawatan kendaraan operasional dan antar jemput pegawai, serta penyempurnaan SOP nya; f) Penyempurnaan SOP diklat, mutasi dan promosi dengan mekanisme yang obyektif.

2. Perlu diciptakan lingkungan kerja yang nyaman, dalam upaya meningkatkan kepuasan kerja sekaligus produktivitas kerja pegawai MKRI. Adapun upaya konkrit yang dapat dilakukan adalah: a) Diselenggarakannya kegiatan-kegiatan yang bertujuan untuk membangun teamwork, seperti outbond, diskusi kelompok, ataupun kegiatan-kegiatan motivasi lainnya secara rutin; b) Penyempurnaan mekanisme reward and pusnishment yang berdasarkan pada prestasi kerja secara obyektif; c) Pengawasan atas penjagaan suasana kerja MKRI yang ramah, kebersamaan, disiplin, transparan, saling mendukung dan menjunjung tinggi kode etik dalam bentuk peraturan yang ketat dan obyektif, sehingga menciptakan suasana kerja yang menyenangkan; d) Diselenggarakan kembali kegiatan coffee morning dan olah raga bersama ataupun kegiatan-kegiatan lain yang dapat menjadi wahana komunikasi informal dalam rangka menambah keakraban antar pegawai, termasuk antara atasan dan bawahan; e) Efektivitas dan efisiensi jam kerja, dan meminimalkan lembur; f) Peningkatan sarana dan prasarana ibadah.

\section{UCAPAN TERIMA KASIH}

Ucapan terima kasih disampaikan kepada Mahkamah Konstitusi khususnya Bagian Perencanaan

Organisasi Sekretariat Jenderal Mahkamah Konstitusi dan PT. Magna Transforma selaku sponsor dalam penelitian ini.

\section{REFERENSI}

Agulu, C.C., \& Aguolu, I.E., 2002, Libraries and information management in Nigeria. Maidugujri: Ed-Linform Services.

Bedner, 2004, Towards Meaningful Rule of Law Research: An Elementary Approach', MS Unpublished, VVI, Leiden; and UNDP (n.d.), 'Access to Justice Practitioner Guide'.

Black, J., 1981, Urban Transport Planning: Theory and Practice, Baltimore: John Hopkins University.

Gaffar. Janedri M., 2009, Kedudukan, Fungsi, dan Peran Mahkamah Konstitusi Dalam Sistem Ketatanegaraan Republik Indonesia, Surakarta, 17 Oktober 2009.

Kristina Setyowati \& Didik Gunawan Suharto. 2007. Kualitas pelayanan di kantor Pertanahan Kabupaten Sragen. Spirit Publik, Vol 3. No 2. p.160-178, Oktober 2007. 
Larasati. Endang, 2008, Reformasi Pelayanan Publik (Public Services Reform) dan Partisipasi Publik, Jurnal IImu Administrasi dan Kebijakan Publik, Vol 5. No. 2, Mei 2008.

Muji Gunarto. 2009. SERQUAL. Diakses tanggal 17 Oktober 2011 jam 19.00 WIB.

Moenir, H.A.S. 2000. Manajemen Pelayanan Umum di Indonesia. PT. Bumi Aksara, Jakarta.

Magribi, La Ode Muhammad, 2004, Impact of Rural Physical Accessibility on Rural Development: Case of rural area in the BUKARI Integrated Economic Development Region, Unpublished PhD. Dissertation (in Indonesian), Gadjah Mada University, Yogyakarta. Press.

Rasyid, Ryaas, 1998. Desentralisasi Dalam Menunjang Pembangunan Daerah Dalam Pembangunan Administrasi di Indonesia. PT. Pustaka LP3ES, Jakarta.

Undang-Undang No 25 Tahun 2009 mengenai Pelayanan Publik.

Wijayanto. Bayu, 2009, Kualitas Pelayanan Publik, Universitas Indonesia.

, A Framework for Strengthening Access to Justice in Indonesia, A national strategy for justice sector reforms in Indonesia. World Bank Publications. 